\title{
Efficacy of Co-Synch Plus CIDR Oestrus Synchronization Protocol on Fertility in Anoestrus Cows and Buffaloes
}

\author{
Sanjeevkumar Patil", M. K. Tandle, R. G. Bijurkar, N. A. Patil, Dilip Kumar, \\ Shrikant Kulkarni and S. Naveen Kumar
}

Veterinary College, KVAFSU, Nandinagar, Bidar, Karnataka, India

*Corresponding author

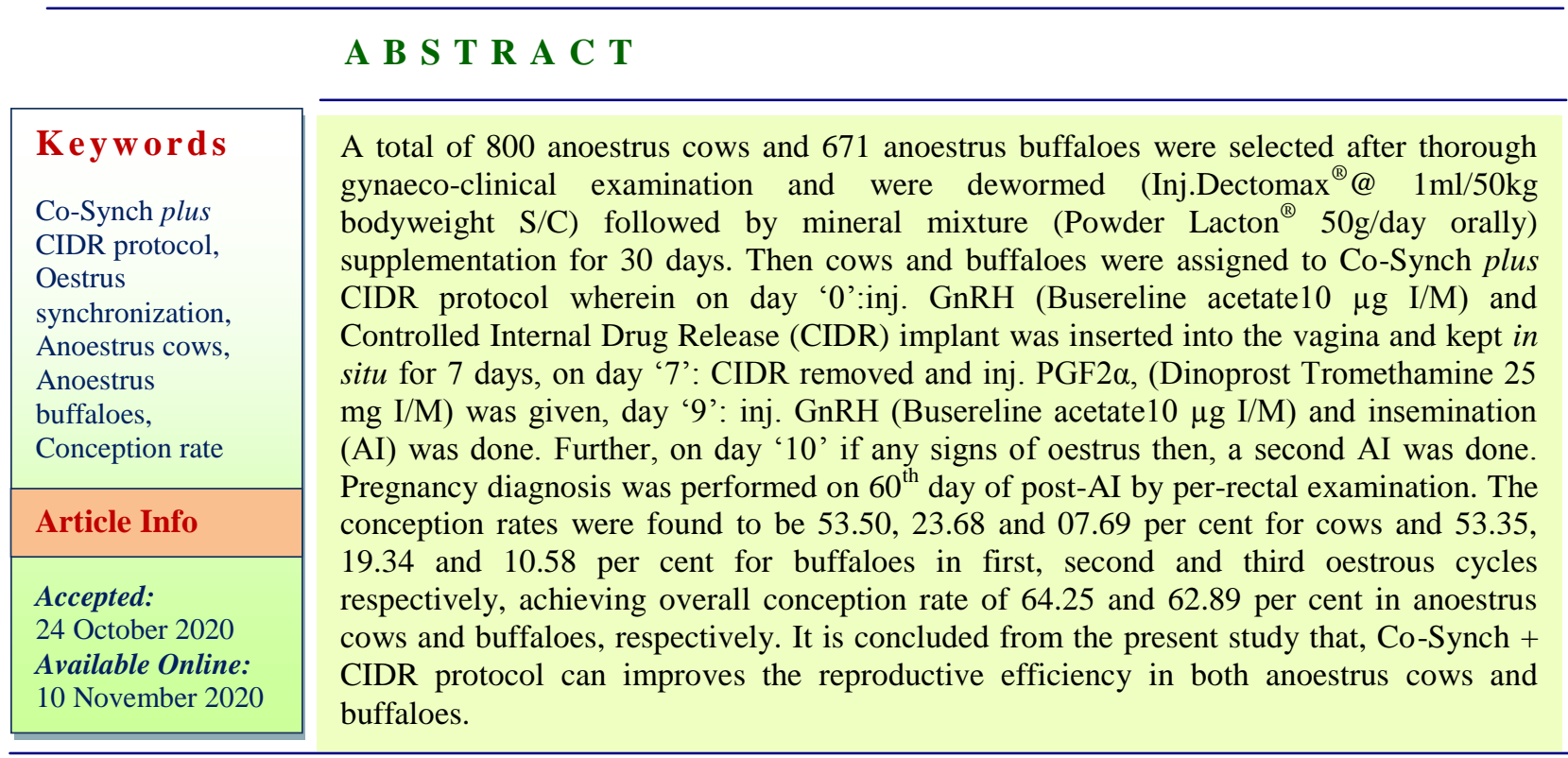

\section{Introduction}

When we look at dairy cows and buffaloes, the reproductive diseases are the most vulnerable problems that incidentally coincide with the reduction of milk production, prolonged uterine involution, resumption of ovarian activity, conception and greater risk to infection (Robert 2000), leading to a reduced profit in the dairy farm. The goal of dairy farms is to get one calf every year, which depends upon the normal function of the reproductive system. The functional ovaries, display estrous behavior, ability to mate, conceive, sustain the embryo through gestation, calve, resume estrous cyclicity and restore uterine function after calving are critical for a cow or buffaloe. Each of these aspects of reproductive function can be affected by management, disease and the genetic make-up of the animal. When the function of reproductive system is impaired, cows or buffaloes fail to produce a calf regularly (Arthur et al., 1996, Noakes et al., 2009). 
Reproductive problems of dairy cows and buffaloes can be classified as before gestation (anoestrous and repeat breeding), during gestation (abortion, vagina prolapse and dystocia) and after gestation (retained fetal membrane, pyometra, metritis and uterine prolapse (Lobago et al., 2006). In India, the incidence of anoestrus was reported from 2.13 to 67.11 per cent for indigenous cattle, 9.09 to 82.50 per cent for buffaloes and for cross bred cattle it is 2.55 to 40.4 per cent (Kumar et al., 2014). Incidence of anoestrus is higher in adult cattle and buffaloes than the heifers (Bharkad and Markandeya, 2003).

To improve reproductive efficiency, several protocols of oestrus synchronization have been developed. Exogenous hormonal administration has been used to treat cows with problem of anoestrus and repeatbreeding (Rhodes et al., 2003; Lucy et al., 2004; Honparkhe et al., 2008; Hailu et al., 2015). One of the most classical and widely used hormone protocols for the induction of ovarian cyclicity was described by Pursley et al., (1995) named as Ovsynch. Controlled Internal Drug Release (CIDR) is another most recent hormone protocol available where progesterone is released from CIDR at a controlled rate into the bloodstream of the animal through vagina and suppresses oestrus and ovulation throughout its duration in situ (Lucy et al., 2001).

The CIDR device was developed by Macmillan et al., (1991) and it is well adopted in synchronizing oestrus consistently that has resulted in high pregnancy rates in cattle regardless of the stage of the estrous cycle. This CIDR can be used in combination with other hormones to synchronize oestrus in cows and buffaloes (Lamb, 2010). Therefore the present research work was undertaken to study the efficacy of Co-Synch plus CIDR protocol in anoestrus cows and buffaloes.

\section{Materials and Methods}

\section{Area of study}

The study was conducted under field conditions at selected villages of Bidar district in collaboration with the Department of Animal Husbandary \& Veterinary Services, Bidar and Department of Gynaecology and Obstetrics, Veterinary College, Bidar, Karnataka state, India from August 2016 to December 2018. Geographically, Bidar district is located in North Interior Karnataka at $17^{0} 35^{\prime}$ to $18^{0} 25^{\prime}$ North latitude and $76^{\circ} 42$ to $77^{0} .39^{\prime}$ East longitudes at an elevation of 640 to 715 meters above the mean sea level.

\section{Selection of anoestrus cows and buffaloes}

The gyneco-clinical health check-up camps were conducted and cows and buffaloes not showing oestrus signs for more than 3 months were selected after ruling out early pregnancy, infectious infertility, anatomical defects and any other pathological conditions. All the animals were dewormed (Inj. Dectomax ${ }^{\circledR} @$ $1 \mathrm{~mL} / 50 \mathrm{~kg}$ bodyweight $\mathrm{S} / \mathrm{C}$ ) and supplemented with mineral mixture (Powder Lacton $^{\circledR} 50 \mathrm{~g} /$ day orally) for 30days. During this period, if oestrus signs were observed, then they were inseminated and excluded from the study group. The anoestrus cows $(n=800)$ and buffaloes $(n=671)$ which did not show any oestrus signs during this period were assigned to Co-Synch plus CIDR protocol.

\section{Co-Synch plus CIDR protocol}

Controlled Internal Drug Release (CIDR) was inserted intravaginally and kept it in situ for 7 days and injection of GnRH (Busereline acetate), PGF2 $\alpha$, (Dinoprost Tromethamine) and Fixed Time Insemination (FTAI) was carried out as shown in flow chart (Figure 1) and various veterinary products used for the present study are mentioned in Table 1. 


\section{Conception rate}

All the inseminated cows and buffaloes were monitored regularly and those cows and buffaloes which did not return to oestrus between 18-24 days post-AI were subjected to pregnancy diagnosis by rectal palpation after 60 days of insemination. First, second and third service conception rates were calculated separately for cows and buffaloes by the percentage of cows/buffaloes found pregnant out of total cows/buffaloes inseminated at first, second or third oestrus. The overall conception rate was calculated by the percentage of cows and buffaloes found pregnant out of the total number of cows and buffaloes inseminated at first, second and third oestrus.

\section{Results and Discussion}

The oestrus response was 100 per cent $(n=800)$ with conception rate of 53.50, 23.68 and 07.69 per cent in first, second and third estrous cycles with an overall conception rate of 64.25 per cent in post-partum anoestrus cows of Co-Synch plus CIDR oestrus synchronization protocol.

Table.1 Drugs and products used for controlled breeding programme in cows and buffaloes

\begin{tabular}{|c|c|c|}
\hline $\begin{array}{l}\text { Sl. } \\
\text { No. }\end{array}$ & $\begin{array}{l}\text { Name of the } \\
\text { product }\end{array}$ & Composition \\
\hline 1 & Inj.: Dectomax ${ }^{\circledR}$ & Doramectin $10 \mathrm{mg} / \mathrm{mL}$ \\
\hline 2 & Powder: Lacton ${ }^{\circledR}$ & $\begin{array}{l}\text { Each } 100 \mathrm{~g} \text { contain: } \\
\text { Niacin: } 30 \mathrm{mg} \\
\text { Sulphur: } 200 \mathrm{mg} \\
\text { Iron: } 200 \mathrm{mg} \\
\text { Calcium Lactate: } 12.5 \mathrm{~g} \\
\text { Sodium Lactate: } 12.5 \mathrm{~g} \\
\text { Sodium Propionate: } 12.0 \mathrm{~g} \\
\text { Base fortified with live } \\
\text { yeast cells as QS. }\end{array}$ \\
\hline 3 & Inj.: Gynarich ${ }^{\circledR}$ & $\begin{array}{l}\text { Busereline acetate } \\
\text { (GnRH analogue) } \\
4 \mu \mathrm{g} / \mathrm{mL}\end{array}$ \\
\hline 4 & Inj.: Lutalyse ${ }^{\circledR}$ & $\begin{array}{l}\text { Dinoprost Tromethamine } \\
5 \mathrm{mg} / \mathrm{mL}\end{array}$ \\
\hline 5 & $\begin{array}{l}\text { EAZI-BREED } \\
\text { CIDR }{ }^{\circledR} \text { Cattle } \\
\text { Insert }\end{array}$ & $\begin{array}{l}\text { Progesterone, } 1.38 \text { gram } \\
\text { per each EAZI-BREED } \\
\text { CIDR Cattle Insert. }\end{array}$ \\
\hline
\end{tabular}


Table.2 Efficacy of Co-Synch plus CIDR oestrus synchronization on fertility in anoestrus cows and buffaloes

\begin{tabular}{|c|c|c|c|c|c|}
\hline \multirow{2}{*}{$\begin{array}{c}\text { Number of } \\
\text { animals }\end{array}$} & \multirow{2}{*}{$\begin{array}{c}\text { Oestrus } \\
\text { response } \\
\%\end{array}$} & \multicolumn{4}{|c|}{ Conception rate $(\%)$} \\
\hline & & $\begin{array}{l}\text { First } \\
\text { cycle }\end{array}$ & $\begin{array}{l}\text { Second } \\
\text { cycle }\end{array}$ & $\begin{array}{l}\text { Third } \\
\text { cycle }\end{array}$ & Overall \\
\hline $\begin{array}{c}\text { Cows } \\
(n=800)\end{array}$ & 100 & $\begin{array}{l}(428) \\
53.50\end{array}$ & $\begin{array}{c}(81) \\
23.68\end{array}$ & $\begin{array}{c}(5) \\
07.69\end{array}$ & $\begin{array}{l}(514) \\
64.25\end{array}$ \\
\hline $\begin{array}{c}\text { Buffaloes } \\
(n=671)\end{array}$ & 100 & $\begin{array}{l}(358) \\
53.35\end{array}$ & $\begin{array}{c}(53) \\
19.34\end{array}$ & $\begin{array}{c}(11) \\
10.58\end{array}$ & $\begin{array}{l}(422) \\
62.89\end{array}$ \\
\hline
\end{tabular}

Note: The values in the parentheses indicates no of animals

Fig.1 Co-Synch + CIDR protocol

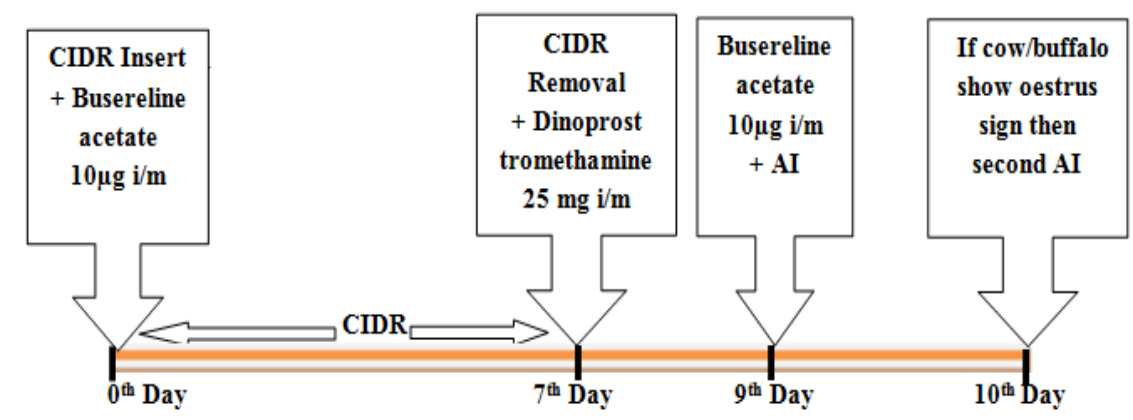

Similar to the present study, Bhoraniya et al., (2012) and Ramalakshmi (2015) used different hormonal protocols in post-partum anestrous Kankrej and crossbred cows, respectively and reported similar conception rates. In contrast, Dhami et al., (2015) reported higher overall of three cycles as 80.00, 80.00 and 70.00 per cent conception rates at induced oestrus by CIDR, Ovsynch, and Norgestomet ear implant protocols in cows, whereas Naikoo et al., (2016) recorded lower overall conception rate as $33.33,50.00$ and 33.33 per cent by using Ovsynch, CIDR and Ovsynch + CIDR treatment protocols with FTAI in post partum anoestrus Kankrej cows respectively and concluded that Ovsynch and CIDR protocol resulted in better oestrus expression and fertility as compared to their combination. Sah et al., (2019) recorded conception rate as $00.00,14.30$ and 12.50 per cent with CoSynch + CIDR,
OvSynch + CIDR and CIDR + PGF $2 \alpha$ protocols respectively in Jersey crosses and Holstein crosses anestrous cows (Table 2).

In present study for buffaloes, the oestrus response was 100 per cent $(n=671)$ with conception rate of $53.35,19.34$ and 10.58 per cent in first, second and third estrous cycles with an overall conception rate of 62.89 per cent in anoestrus buffaloes of Co-Synch + CIDR oestrus synchronization protocol.

The present research findings are in line with Kundulkar et al., (2016) who observed first service conception rate of 50.00 and 62.50 per cent in lactating post partum anoestrus buffaloes by Ovsynch and Ovsynch +CIDR protocols, respectively. Parmer et al., (2017) recorded conception rates of 33.33 and 28.57 per cent at induced oestrus and overall conception rates as 66.66 and 57.14 per cent 
in true anoestrus buffaloes treated for CIDR and Ovsynch protocol, respectively. Further, their study indicated that hormonal therapies used particularly CIDR and Ovsynch protocols improved conception rates in anoestrus buffaloes under field conditions. In addition, Patel et al., (2018) recorded conception rate at induced oestrus as 27.30 , 27.30, 18.20 and 45.40 per cent with an overall conception rate of three cycles as 63.60, 54.50, 63.60 and 81.80 per cent which were much higher than control anoestrus buffaloes $(18.20 \%)$ by using Doublesynch, Estradoublesynch, Triu-B/PRID, PRID + PMSG and untreated control, respectively. Prasad et al., (2019) also recorded conception rate as 60,50 and 33 per cent in postpartum anoestrous graded Murrah buffaloes by using Ovsynch, double PG protocol (sub-estrus), and normal cyclic without any hormonal interventions, respectively. Similarly, Narote et al., (2019) recorded first service conception rate as $44.44,37.50,44.44,37.40,40.00$ and 33.33 per cent respectively. Overall conception rate recorded as 77.77, 75.00, $88.88,87.50,70.00$ and 88.88 per cent and pregnancy rate recorded as 58.33, 50.00, $66.66,58.33,58.33$ and 66.66 per cent in anestrous buffaloes in CIDR-7-PG, CIDR-9PG, CIDR-7-PG-GnRH-AI, CIDR-9-PGGnRH-AI, CIDR-7-PG-GnRH-insert, CIDR9-PG-GnRH-insert, respectively.

In contrast, Rensis et al., (2005) reported lesser conception rate of 4.70 and 30.00 per cent in Ovsynch and Ovsynch with the supplementation of progesterone from days 0 to 7 in non-cyclic Mediterranean Italian buffaloes, respectively. Azawi et al., (2012) also recorded pregnancy rate of 5.00 and 31.80 per cent in postpartum anoestrus buffaloes using GnRH-PG-GnRH and GnRHCIDR-PG-GnRH Protocols.

However, higher first service conception rate of 83.30 per cent in 54 anestrous buffaloes suffering from ovarian inactivity with the treatment regime of CIDR 7-PG-GnRH was recorded by Zaabel et al., (2009). Naikoo et al., (2010) also observed pregnancy rate of 50.00 in Ovsynch, 50.00 in CIDR and 83.33 per cent in Ovsynch-CIDR respectively protocols in postpartum anestrous Mehsana buffaloes during breeding season. Similarly, Nakrani et al., (2014) recorded overall conception rates of 66.67, 73.33 and 60.00 per cent in anoestrus buffaloes in CIDR, Ovsynch and Crester protocols respectively. In addition, Savalia et al., (2014) reported overall conception rate of three cycles as 70.00 and 60.00 per cent at induced oestrus for CIDR and Ovsynch groups respectively in true anestrous buffaloes in CIDR or Ovsynch protocols. Vikash et al., (2014) also reported higher conception rate and pregnancy rate as 81.26 per cent in anoestrus buffaloes with CIDR-GnRH combination. In addition, Ghallab and Noseir (2016) recorded conception and pregnancy rates as 72.20 and 65.00 per cent in post partum anoestrus Egyptian buffaloes with CIDR-PG protocol. Similarly, Savani et al., (2017) recorded conception rates of 66.66 and 50.00 per cent at induced oestrus and overall conception rates as 75.00 and 66.66 per cent in anoestrus Surti buffaloes treated with Ovsynch and Ovsynch + PRID protocol respectively.

It is concluded from the present study that Co-Synch plus CIDR protocol improves the reproductive efficiency of cows and buffaloes as observed with enhanced conception rates in first, second and third service along with overall conception rates of 64.25 and 62.89 per cent in anoestrus cows and buffaloes.

\section{References}

Ahmed, A., Tiwari, R.P. and Mishra, G.K., 2016. Bio-stimulatory effects of bull urine (BU), PRID and GnRH on estrus induction and ovarian activity in 
pubertal anestrus Sahiwal heifers. The Indian Journal of Animal Sciences., 86(6):643-647

Arthur GH, Noakes DE, Pearson H, Perkinson TJ (1996) Veterinary Reproduction and Obstetrics. Theriogenology (4th edn), Bailliere Tindal Great Britain, UK, pp. 291-301

Azawi, O.I., Ali, M.D., Ahmed, O.S., AlHadad, A.S., Abeh Jamil, M.S. and Hussien, A.S.A., 2012. Treatment of anestrous in Iraqi buffaloes using Ovsynch alone or in combination with Cidr. Journal of Advanced Veterinary Research., 2(2):68-72

Bhoraniya, H.L., Dhami, A. J., Naikoo, M., Parmar, B. C. and Sarvaiya, N. P., 2012. Effect of estrus synchronization protocols on plasma progesterone profile and fertility in postpartum anestrous Kankrej cows. Trop Anim Health Prod., 44:1191-1197

Dhami, A.J., Nakrani, B.B., Hadiya, K.K., Patel, J.A. and Shah, R.G., 2015. Comparative efficacy of different estrus synchronization protocols on estrus induction response, fertility and plasma progesterone and biochemical profile in crossbred anestrus cows., Veterinary World., 8(11): 1310-1316

Dudi. V,. 2016. Efficacy of different estrus synchronizing protocols and subsequent fertility in cyclic and noncyclic cows. M.V.Sc. Thesis, Rajasthan University of Veterinary and Animal Sciences, Bikaner, India.

Ghallab, R.S. and Noseir, W.M., 2016. Comparative efficiency of different CIDR protocols for treatment of postpartum anestrous in Egyptian buffaloes. Alexandria Journal of Veterinary Sciences, 49(2), pp.149156.

Hailu, B., Gebrekidan, B., Raju, S., Birhanu, A. and Tadesse, G., 2015. Effects of gonadotrophin releasing hormone analogue in enhancements of pregnancy in repeat breeding dairy cows in and around Mekelle, Tigray, Ethiopia Anim. Vet. Sci., 3(1): 12-17

Honparkhe, M., Singh, J., Dadarwal, D., Dhaliwal, G. S. and Kumar, A., 2008. Estrus induction and fertility rates in response to exogenous hormonal administration in post partum anestrus and subestrous bovines and buffaloes. J. Vet. Med. Sci., 70: 1327-1331

Kumar, P.R., Singh, S.K., Kharche, S.D., Govindaraju, C.S., Behera, B.K., Shukla, S.N., Kumar, H. and Agarwal, S.K., 2014. Anestrus in cattle and buffalo: Indian perspective. Adv. Anim. Vet. Sci, 2(3), pp.124-138

Kundulkar A.D., Ingawale, M.V., Deshmukh, S.G., Hajare, S.W. and Ingole, R.S., 2016. Absence of potential benefit of progesterone priming during ovsynch prptocol in post partum anoestrus buffaloes near the end of breeding season. Indian Journal of Animal Reproduction., 37(2):61-62

Lamb, G. C., Dahlen, C. R., Larson, J. E., Marquezini, G. and Stevenson, J. S., 2010. Control of the oestrous cycle to improve fertility for fixed-time artificial insemination in beef cattle: a review. J. Anim. Sci., 88(13 Suppl): E181-192

Lobago, F., Bekana, M., Gustafsson, H. and Kindahl, H., 2006. Reproductive performances of dairy cows in small holder production system in Selalle, Central Ethiopia. Trop Anim Health Prod., 38: 333-342

Lucy, M. C., Mcdougall, S. and Nation, D. P., 2004. The use of hormonal treatments to improve the reproductive performance of lactating dairy cows in feedlot or pasture-based management systems. Anim. Reprod. Sci., 83: 495512

Lucy, M.C., Billings, H.J., Butler,W.R., 
Ehnis, L.R., Fields, M.J., Kesler, D.J., Kinder, J.E., Mattos, R.C., Thatcher, W.W., Wettemann, R.P., Yelich, J.V. and Hafs, H.D., 2001. Efficacy of an intra vaginal progesterone insert and an injection of PGF2 $\alpha$ for synchronizing estrus and shortening the interval to pregnancy in postpartum beef cows, peripubertal heifers and dairy heifers. J. Anim. Sci., 79: 982-995

Macmillan, K.L., Taufa, V.K., Barnes, D.R. and Day, A.M., 1991. Plasma progesterone concentration in heifers and cow treated with a new intar vaginal device. Anim Reprod Sci., 21: 25-40

Naikoo, M., Dhami, A.J. and Ramakrishnan, A., 2016. Effect of estrus synchronization on plasma progesterone profile and fertility response in postpartum suckled anestrous Kankrej cows. Indian Journal of Animal Research., 50(4):60465

Naikoo, M., Patel, D.M., Sarvaiya, N.P. and Killader, A., 2010. Estrous synchronization in postpartum anestrous Mehsana buffaloes using different hormone protocols. Indian Journal of Field Veterinarians (The)., 6(2): 1 .

Nakrani, B.B., Panchal, M.T., Dhami, A.J., Hadiya, K.K., Patel, J.A. and Gosai, R.K., 2014. Effect of controlled breeding techniques on fertility and plasma profile of biochemical and mineral constituents in anoestrus buffaloes. Scholars J. Agric. Vet. Sci., 1(4B): 299-304

Narote, K.V., 2019. Comparative efficacy of different CIDR protocols for treatment of anestrus in Buffaloes. M.V.Sc. Thesis, Maharashtra Animal and Fishery Sciences University, Nagpur, India.

Noakes, D.E., T.J. Parkinson and G.C.W.
England, 2009. Veterinary Reproduction and Obstetrics. 8 ed. London: Elsevier Limited, pp: 393-455

Parmar, B.N., Patel, D.M., Vijyeta, H.P. And Parikh, S.S., 2017. Controlled breeding techniques for enhancing reproductive performance of buffaloes. Indian Vet. J., 94(5):33-35

Patel, A. J., Dhami, A. J., Prajapati,.J.P and Parmar, S.C., 2018. Estrus induction, fertility and biochemical profile in true anestrus Surti buffalo following different oestrus synchronization protocols. Indian Journal of Animal Reproduction., 39 (2):36-39

Prasad, B.C., Srinivas, M. and Rao, K.S., 2019. Comparative efficacy of Ovsynch and double PG protocols in postpartum anoestrus graded Murrah buffaloes (Bubalus bubalis). Journal of Livestock Science., 10: 6-8.

Pursley J.R, Mee, M.O. And Wiltbank, M.C., 1995. Synchronization of ovulation in dairy cows using PGF2 $\alpha$ and GnRH. Theriogenology., 44: 915-923

Ramalakshmi, N. 2015. Synchronization of estrus and ovulation in postpartum acyclic crossbred cows. M.V.Sc. Thesis, Sri Venkateswara Veterinary University, Tirupati, India

Rensis, De. F., Ronci, G., Guarneri, P., Nguyen, B.X., Presicce, G.A., Huszenicza, G. and Scaramuzzi, R.J., 2005. Conception rate after fixed time insemination following ovsynch protocol with and without progesterone supplementation in cyclic and noncyclic Mediterranean Italian buffaloes (Bubalus bubalis). Theriogenology., 63(7):1824-1831

Rhodes, F. M., Mcdougall, S., Burke, C. R., Verkerk, G. A. and Macmillan, K.L. 2003. Invited review: treatment of cows with extended postpartum anestrus interval. J. Dairy Sci., 86: 1876-1894. 
Robert, S. J., (2000) Veterinary Obstetrics and genital diseases. Theriogenology (5th edn). Edwards' Brothers, Inc., Michigan, p. 48-104

Sah.A K., Gautam.G., Pathak.L.R and Pandeya. Y R., 2019. CIDR based hormonal protocols effect upon fertility in anestrous cows at the farm of national cattle research programme, Rampur, Chitwan". EC Veterinary Science., 5 (2): 01-06.

Savalia, K.K., Dhami, A.J., Hadiya, K.K., Patel, K.R. and Sarvaiya, N.P., 2014. Influence of controlled breeding techniques on fertility and plasma progesterone, protein and cholesterol profile in true anestrus and repeat breeding buffaloes. Vet World., 7(9): 727-732.
Savani, H.R., Khasatiya, C.T., Saxena, S. and Patel, M.D., 2017. Estrus induction and fertility response following Ovsynch alone and Ovsynch plus PRID protocol in post partum anestrus Surti buffaloes. Indian Journal of Veterinary Sciences \& Biotechnology., 12(4):1-4

Vikash, V.M., Malik, R.K. and Singh P., 2014. Impact of CIDR in combination with different hormones for treatment of anestrus in buffaloes under field conditions of Haryana. Haryana Vet, 53: 28-33.

Zaabel, S.M., Hegab, A.O., Montasser, A.E. and El-Sheikh, H., 2009. Reproductive performance of anoestrous buffaloes treated with CIDR. Anim. Reprod., 6(3): 460-464.

\section{How to cite this article:}

Sanjeevkumar Patil, M. K. Tandle, R. G. Bijurkar, N. A. Patil, Dilip Kumar, Shrikant Kulkarni and Naveen Kumar, S. 2020. Efficacy of Co-Synch Plus CIDR Oestrus Synchronization Protocol on Fertility in Anoestrus Cows and Buffaloes. Int.J.Curr.Microbiol.App.Sci. 9(11): 3488-3495. doi: https://doi.org/10.20546/ijcmas.2020.911.416 